\title{
Sodium-Coupled Neutral Amino Acid Transporter 3
}

National Cancer Institute

\section{Source}

National Cancer Institute. Sodium-Coupled Neutral Amino Acid Transporter 3. NCI

Thesaurus. Code C111849.

Sodium-coupled neutral amino acid transporter 3 (504 aa, $\sim 56 \mathrm{kDa}$ ) is encoded by the human SLC38A3 gene. This protein is involved in neutral amino acid transport. 